\title{
POST-WAR NEW ZEALAND
} LITERARY CRITIQUE

\author{
James Smitbies
}

\begin{abstract}
For most of the 20th century literature and criticism of literature functioned as central engines of cultural change across the western world. This was especially the case in ex-colonial societies like New Zealand where writers and intellectuals frequently expressed a desire to create sophisticated local cultures which could compete with the foundation societies in Europe. Between 1940 and 1984 New Zealand writers and intellectuals developed a mode of literary criticism which this essay refers to as 'Literary Critique' for this very reason. In the absence of well established cultural traditions and a sense that they had a duty to import and indigenise western intellectual thought in order to further the evolution of New Zealand culture, a series of writers wrote often scathing critiques of their culture, using literature as their point of entry. PostWar New Zealand Literary Critique stands as evidence of a provincial, masculine, and angry intellectual culture.
\end{abstract}

KEYWORDS critique $\bullet$ culture $\bullet$ literature $\bullet$ masculinism $\bullet$ modernism $\bullet$ New Zealand • post-modern

In The Bookmen's Dominion, Chris Hilliard points out that '[t]he history of creative and intellectual activity is not just the history of great minds' (Hilliard, 2006: 120). Social and cultural infrastructures such as writers' societies and libraries play a fundamental role in the development of a literary and intellectual culture, without which 'great minds' could not find an outlet for their writing. His comment is an implicit warning against cultural nationalist claims for intellectual exceptionalism. But New Zealand has never been in danger of claiming intellectual exceptionalism; indeed, New Zealand culture has long been noted for a strong strain of anti-intellectualism and denigration of local intellectual activity. Within this context it is important that we try to identify people who made concerted efforts to bring new ideas into the country and to create a robust intellectual tradition. Their writing represents

Thesis Eleven, Number 92, February 2008: 87-106

SAGE Publications (Los Angeles, London, New Delhi and Singapore)

Copyright (c) 2008 SAGE Publications and Thesis Eleven Co-op Ltd

DOI: $10.1177 / 0725513607085046$ 
an effort to build an intellectual culture capable not only of defining the central features of their country, but of engaging with ideas present in the outside world. In the case of New Zealand, those people also developed a notable literary genre, which can be usefully referred to as 'literary critique'.

Although literary taxonomy has been largely abandoned since the work of Northrop Frye during the mid-20th century, it can still be justified in a postmodern environment where critics demand attention to the solubility of generic boundaries, because the identification of new modes of writing can shed light on important cultural practices. If we abandon older restrictive methods of genre analysis based on formal classification, and follow the path suggested by more recent theorists like M. M. Bakhtin and Tzvedan Todorov, we can move towards a conceptualization of genre 'as a rhetorical and essentially semiotic social construct' (Devitt, 1993: 573) which exhibits 'an extraordinary sensitivity to all fluctuations in the social atmosphere' (Bakhtin cited in Devitt, 1993: 579). Such an approach allows us to investigate the complex way that literary form relates to social and cultural patterns. In the case of New Zealand culture it allows us to examine the development of literary critique as one adaptive response' (Fairburn, 2006: 152) to New Zealand's cultural conditions.

Reviewing an intellectual tradition using taxonomic principles has the added benefit of depersonalizing the activity because this places personality, bias, and the implications of searching after 'great minds' at a safe remove. The important point is that the essays were written, performed a set of functions, and the genre was used often enough over time to constitute a tradition. Similarly, claims to exceptionalism are naturally diffused through the common access of all Western societies to the essay form, literary criticism and the literary canon itself. Literary critique is a local manifestation of a genre common across the Western Tradition generally. Perhaps the most striking nature of the genre is the peculiarly negative tone most of the writers took towards New Zealand, often noting that their home country and New Zealanders were backward, maladapted and emotionally repressed. Cultural negativity is hardly exceptional, but it can seem an odd way to express nationalist sentiment. It has much in common with the post-war bourgeois critiques of middle Britain and middle America undertaken by the likes of T. S. Eliot, F. R. and Q. D. Leavis and Lionel Trilling.

While 'New Zealand literary critique' should not be viewed in strictly formalist taxonomic terms, the label refers to a reasonably specific, and significant, intellectual tradition. It could be suggested that the genre gains it cohesiveness through the author's intentions more than any specific textual markers. The New Zealand literary critic most aware of the mode of writing, Roger Horrocks, touched on this when he noted in 1982 that

[t]here is a certain type of essay that gives the impression of bursting at the seams because it wants to argue with our whole culture, our whole set of artistic habits and values. (Horrocks, 1982: 87) 
Horrocks' 'certain type of essay' fulfilled an important need in New Zealand culture over the course of the late 20th century: it provided a conversation that writers and intellectuals could enter into regardless of their political, ideological or cultural perspectives. New Zealand literary critique provided a forum for the analysis of New Zealand culture through the medium of its literature. Outside the exigencies of editorial processes there were few barriers to what could be said or what perspectives could be offered. In some ways the genre functioned as a key engine for the cultural development of New Zealand culture, so almost any new perspectives were welcomed. Writers like Robert Chapman, Bill Pearson and James K. Baxter were eager to point out that the exigencies of colonization and settlement had led to a culture characterized by anti-intellectualism borne of materialism, stagnation and conformity. The genre acted as 'a clearing house for ideas' (Holcroft, 1948: 17), allowing commentators to offer new perspectives and assist in the construction of what they felt would be a more sophisticated local culture.

Of course, it would be reactionary to suggest that the genre represented a tradition of unmitigated intellectual, political and cultural freedom. It has also reflected and contributed to cultural constraints, providing overt evidence for the domination of New Zealand intellectual culture by Pakeha men. ${ }^{1}$ No significant literary critiques were written by women or minority groups until Michele Leggot's 'Opening the Archive' in 1995, a decade after the tradition began to fall into disuse. Given the central position the genre has had in the construction of New Zealanders' understanding of themselves, this is significant. As Kai Jenson has noted, New Zealand literature (and culture) has been dominated by cliques of men eager to create a solid, masculine tone that could compete with a culture they believed was based on rugby, racing and beer. Literature and high culture were held to be suspect across many sectors of New Zealand culture for much of the late 20th century as purveyors of art, effeminacy and (quite probably) homosexuality. The men contributing to local literary critique battled this perception, in part, by excluding women in an effort to look more manly themselves, and although they achieved their ends of furthering the development of a more sophisticated local culture, they also contributed to the marginalization of women and other minority groups. The identification of the genre offered here is not, therefore, wholly celebratory; it is documentary and acknowledges that New Zealand literary critique may be in abeyance for good reasons.

It is inaccurate to cite New Zealand culture as the only influence on the genre, though. The genre is implicated in a broader global tradition of public commentary via essay writing and literary-cultural analysis which explains both its reactionary and highly liberal tendencies; it is a tradition which represented one of the core technologies for the negotiation of power across the post-Enlightenment world, beginning on the Continent with Charles SainteBeuve, Stephane Mallarme and Paul Valery, crossing the English channel through Matthew Arnold, and reaching its zenith in the high modernism of 
mid-20th-century literary critics as varied as the Leavises, T. S. Eliot, Gertrude Stein, Wyndham Lewis and Lionel Trilling. The practice was co-extensive with the professionalization of English studies over the course of the 20th century and the movement of this discipline into the academy. It continues today, although in a much altered cultural context.

It will also come as no surprise that literature has provided an important point of focus for New Zealand's cultural critics. As suggested earlier, the essay form was put to its most powerful use in Europe when used to interpret literature during the late 19th and early 20th centuries. Robert Davis and Ronald Schleifer suggest that this coincided with literature being viewed as a potentially redemptive force in society which justified its being exposed to the rigours of post-Kantian and post-Hegelian logic. Once applied to literature, the 'terrible learning' of critique allowed critics to produce penetrative cultural essays which pointed to the deeper lessons held within each literary product (Davis and Schleifer, 1991: 25). As the interpreters of literature, literary critics came to be viewed as central to cultural development, as the new Jeremiahs, a secular ministry for an industrialized and secularizing age. Transformative critique such as that practised in New Zealand thus aims at first identifying and then altering false or distorted consciousness. Significantly, the approach is suggestive of a group of people positioned both within and against their culture. Terry Eagleton put the matter succinctly when he noted that:

The most effective critique of Bourgeois society is accordingly one that like Marxism is 'immanent', installing itself within the very logic of that order's most cherished values in order to unmask the necessary disconnection of this ideal universal realm from the sordidly particularistic appetites it serves to mystify. (Eagleton, 1990: 31)

This may be why many examples of transformative critique have centred on literature for their source material: literature and literary criticism came to be viewed as central bastions of cultural value across much of the postEnlightenment world. ${ }^{2}$

Perhaps surprisingly, one of the better parallels to New Zealand in this regard is Russia. As both Ralph Matlaw and Isaiah Berlin have noted (Berlin, 1999), 19th-century literary critics such as Belinsky, Chernyshevsky and Dobrolyubov were central to the development of both Russian literature and modern Russian intellectual thought. They recognised that the task of modernizing Russian culture could be aided by a vibrant literary culture, and that required a vibrant culture of criticism. In less generous spirit, we could note, along with Ralph Matlaw, that they 'used literary masterpieces as springboards for their own views' (Matlaw, 1976: xiii).

The commitment to modern criticism in New Zealand literary criticism was instigated by the Phoenix generation of student writers based at the University of Auckland. Their magazine Phoenix (1932-3) was developed in overt opposition to what they viewed as aesthetic flights of fancy on the 
part of late colonial writers imbued with a Georgian method and a romantic cast of mind easily captured by archaism, be it Maori, Ossianic or Celtic in origin (Stafford and Williams, 2006). The Phoenix group opposed the deeply aesthetic vision of the 'Maoriland' writers and their congratulatory critics, and yearned for a hard-edged, masculine mode of criticism which would use the social realist strain of modernism to show New Zealanders who they were. It was a heroic project offered in direct opposition to aestheticism, 'lady versifiers' and amateur critics. In the first edition of Phoenix one contributor, D'Arcy Cresswell, went so far as to suggest that New Zealand's 'dawning manhood demanded such a paper' (Cresswell, 1932: 5). There was no effective rejoinder and the movement burgeoned into a mode of cultural nationalism which used literature and criticism to develop the cultural capital of the country. The project found its feet during the Second World War and culminated during the 1950 s and 1960 s in a brand of historically and sociologically inspired literary criticism which took New Zealand culture apart and proclaimed it an intellectual wasteland.

Without wanting to define a monolithic genre based on a rigid formal typology, I refer to this tradition as literary critique. Between 10 and 15 essays of this nature were produced in New Zealand between 1940 and 1984 (10 are referred to in this article), when opinion shifted against cultural nationalism and the belief in the need for socially (or more accurately, culturally) committed criticism. Literary critique provides a significant load-bearing beam of New Zealand liberal culture, and a record of the country's intellectual preoccupations. This is perhaps best described through the first professional, national, literary history, E. H. McCormick's Letters and Art in New Zealand (1940). McCormick neatly symbolizes the change in New Zealand's intellectual culture which occurred during and after the Second World War. Unlike earlier 'gentlemanly' critics who were untrained amateurs or journalists, he had an M. Litt. in literary criticism from Cambridge University (McCormick, 1935), where he studied under the historian of ideas Basil Willey and frequented F. R. Leavis' weekly tea parties for students. He symbolizes the professionalization of literary studies and suggests the new attitude of the country's cultural critics who wanted to raise the quality of cultural products. McCormick returned to New Zealand before his Cambridge thesis was completed and was appointed Hocken Librarian at the University of Otago in 1936. In 1937 he was made secretary to the national centennial committee, which had responsibility for organising the New Zealand centennial in 1940.

Letters and Art was part of an 11-volume set commissioned by the New Zealand government for the 1940 centennial celebrations; the aim was to create a cultural and artistic infrastructure, and literature was believed to be central to this effort. New Zealand's first professional literary history was, therefore, state-inspired. For McCormick,

the 'idea' which seems to me of fundamental importance in any consideration of New Zealand history is this; that one hundred years ago a sample of nineteenth 
century society and civilisation was transferred to New Zealand and has since been reshaped and adapted, with varying degrees of success, to conform to the conditions of a new environment. (McCormick, cited in Booker, 1983: 120)

McCormick's aim in writing Letters and Art was to trace the transference of the Western tradition to New Zealand, and to note the ways in which it had been transformed in the new environment. His approach was heavily influenced by Leavisite organicism (F. R. Leavis himself encouraged McCormick to undertake the work while at Cambridge) which envisaged the new culture as an outgrowth of the British trunk, albeit an outgrowth struggling to find its voice using themes of isolation, exile and spiritual alienation.

M. H. Holcroft's The Deepening Stream: Cultural Influences in New Zealand (1940) was another product of the centennial celebrations (it won the essay prize), and represents this perfectly. Holcroft differed from McCormick, however. He grew up in Christchurch and was educated at Christchurch Boys' High School before taking a position as office boy at a biscuit and confectionery factory in 1917. After two years, he made his way to Sydney where he settled as a dockyard clerk, short story writer and budding novelist, publishing in a wide variety of Australian periodicals such as The Australian Journal, Punch, Triad, Smith's Weekly, Bulletin and others. During his time in Sydney he was involved in a failed marriage and gathered the background to the second of several failed novels. ${ }^{3}$ After his marriage crumbled, Holcroft returned to New Zealand, where he started his journalistic career as a subeditor of the Christchurch Press before embarking for London in late 1928. He returned to New Zealand in 1930 after successive attempts to survive as a novelist.

In many ways Holcroft's The Deepening Stream reflected an extension of McCormick's themes of isolation, exile and spiritual malaise. He adopted a more aesthetic style and became enamoured with a mode of antimodernism that owed debts to the central European materialist philosophies of Goethe and Schiller - mediated, it has to be noted, via Rudolf Otto and the fantastically successful British writer Havelock Ellis. Yet, despite his different intellectual interests, Holcroft's writing reflected similar preoccupations to McCormick, especially in his fascination with the transference of culture to the antipodes, which he presented as mildly Arcadian prior to Polynesian settlement:

This, then, is the basic fact of our history - an age of silence. While the countries of Europe and Asia felt the movement of tribes and the growth of nations; while the classic civilizations were tumultuously taking their shape in the Mediterranean basin; while barbaric empires developed, with splendous [sic] of mythology and ritual, in the broad lands of South America; while the dream of spirit in nature was creating the colourful but passive culture of India: the islands of New Zealand were outside the mind of the world, intact and pure amid the flow of winds which brought only the sound and the distilled moisture of the sea. (Holcroft, 1943: 59) 
It is not difficult to understand why the cultural nationalists placed so much significance on literature as a vehicle for the transference of culture to the antipodes: there appeared to them to be an opportunity to create something entirely new in New Zealand, based on the best thought of Europe. They took the responsibility seriously. It is important to note that despite the cultural nationalists' insistence that art and literature contribute to the cultural and intellectual development of the nation, they did not confuse these with propaganda or blind liberal moralism, as later critics seem to imply. They did not demand that 'art abandon its proper end and tend to other needs' (Berlin, 1999: 217); rather that its social, cultural and artistic functions were one and the same.

Allen Curnow's seminal introduction to the Penguin Book of New Zealand Verse, 1923-1945 reflects this attitude. He famously stated that 'reality must be local and special at the point where we pick up the traces' (Curnow, 1945: 17), in opposition to those who would retreat into a rarefied aesthetic world populated by indigenous Maori maidens, indigenous flora and Kiwis; he felt that a retreat into an unreal Maoriland amounted to an abrogation of responsibility on the part of the artist. It is a noted declaration from one of the country's most respected poets (and a central member of the cultural nationalist movement who refused to leave the country until he was an established figure) which implies a demand for unity between the social, cultural and artistic elements of New Zealand society. That it is predicated upon an unfair disdain for the Maoriland writers for eschewing poetry of social significance does not render it false.

Curnow died in 2001 at the age of 90. Alongside Janet Frame he is considered one of New Zealand's most accomplished writers of the late 20th century. His development of literary critique in his introduction to $A B o o k$ of New Zealand Verse tangibly set the poet and writer at the centre of articulations of New Zealand identity, asserted the need for poets to take on a public role, and provided local writers and artists with a manifesto which dominated their practices for the next 40 years. Although he wrote the beguiling lines 'In your atlas two islands not in narrow seas / Like a child's kite anchored in the indifferent blue' (Allen Curnow, 1945: 137), Curnow did not always emphasize New Zealand's isolation. In his most famous critical passage he suggested that:

The idea that we are confronted by a natural time, a natural order, to which our presence in these islands is accidental, irrelevant; that we are interlopers on an indifferent or hostile scene; that idea, or misgiving, occurs so variously and so often, and in the work of New Zealand poets otherwise so different, that it suggests some common problem of the imagination. (Curnow, 1945: 52)

Curnow's introduction (and the anthology of poems which followed) marked a distinct break; it provided New Zealand writers with a powerful assertion that Maoriland and flights of fancy had been replaced with a hardened, modern mode of writing, criticism and cultural production. 
There was no clear rejoinder to the cultural nationalist project outlined by McCormick, Holcroft and Curnow for several decades. As will be seen, writers like James K. Baxter and Kendrick Smithyman produced essays which weakened the power of the nationalist position while the appearance of feminism and postmodernism effectively undermined its illiberal tendencies, but it was 40 years before New Zealand saw a formal rejoinder which clearly identified the issue at hand and spoke to its central premises.

A cynic would suggest that this widespread demand for a literature of social significance was a direct result of the Puritan tradition in New Zealand culture: that the moral precept at the centre of this demand was a hangover from some kind of repressed Scottish inheritance. Frank Sargeson's short story 'Sale Day' presented this issue in stark form, when at its close the central protagonist explodes at the randy tomcat rubbing his legs by picking it up and throwing it into the stove. It represents a theme of not only sexual denial and emotional repression, but the dangers of an overly masculinist society; dangers common to colonial cultures, but more pronounced in an under-populated country as isolated as New Zealand. Sargeson was influenced by the social realist school and strove to represent New Zealand culture as realistically as he could in artistic form, but subsequent critics took his creative message somewhat further.

This was evident in Robert Chapman and Bill Pearson's essays, produced independently in 1952 and 1953 (Chapman wrote from New Zealand while Pearson was in London), which used a combination of sociological analysis and Leavisite didacticism to launch an eviscerating moral campaign against New Zealand culture. Published in Landfall during 1953, Chapman's essay 'Fiction and the Social Pattern' has been 'widely regarded as a seminal work on New Zealand literature and society' (McCleay, 1999: 8), establishing the author as an important commentator on New Zealand society and politics. Chapman was born in 1922 and trained as a historian at the University of New Zealand, gaining an MA and teaching New Zealand and American 20th-century history before becoming a professor of political studies at the University of Auckland. The Oxford Companion to New Zealand Literature cites F. R. Leavis as a major critical influence on Chapman, especially in his belief that fiction writers should aim to highlight aspects of society that lead to the destruction of human life and values. The stance was highly didactic, in that it aimed to use the criticism of literature to alter opinions towards human existence, by highlighting the social comments made by authors on their society. It was this Leavisite position that lent literary critique its role as arbiter of cultural truths, and designated the literary critic as social and cultural commentator. Like the Russian critic Dobrolyubov, Chapman and Pearson held a 'conception of criticism as concerned with the assessment of literature solely as a weapon of sociological analysis' (Berlin, 1999: 221).

Born in Greymouth, a coal town on the South Island's west coast, Pearson attended Canterbury University College and trained as a teacher in 
Dunedin before he taught at the west coast's remote Blackball school. Returning to New Zealand after service in the Second World War as a noncombatant, he completed an MA at Canterbury before moving to England where he undertook a $\mathrm{PhD}$ at the University of London. After a period teaching in England he returned to New Zealand and lectured at Auckland University College from 1959.

Chapman and Pearson's essays are still required reading in undergraduate courses in New Zealand literature and culture, notable for their piercing critique of a society characterized by uniformity, anti-intellectualism, homophobia and, most importantly, Puritanism. In many ways their essays stand as the central documents in the history of New Zealand literary critique. The attitude was common to counter-cultural movements across the world, but in New Zealand (as with America), critics like these became hung up on the issue of a Puritan inheritance perpetuated through a set of repressive cultural norms:

The outlook and the moral scheme [of the Victorian evangelicals] were not lost in the cabins and holds of the emigrant ships coming to New Zealand. They travelled better in the habits and attitudes of the immigrants than the Churches could with their buildings, halls, schools, hospitals and vicarages. The Churches which had been associated with the elaboration of the puritan pattern tended increasingly over the decades to be left out. (Chapman, 1953: 36)

We are the most puritan country in the world, yet we love a dirty story. (Pearson, 1952: 209)

There is a dimension of experience the New Zealander does not know. Because he is afraid of that accursed self of his that might get off-side of his normridden society. (Pearson, 1952: 213)

The moral outrage of Chapman and Pearson's essays was hidden in sociological analysis, but the aim was clear: to use literature to critique the fundamental building blocks of mid-20th-century New Zealand culture. It reflected a step beyond the genteel attitude of cultural nationalists like McCormick, Holcroft and Curnow and in some senses signalled a declaration of war against a culture they felt was inward looking, provincial and unhealthy. One of Pearson's later essays, 'The Maori and Literature', used Pakeha writing about Maori to slam New Zealand culture as inadequate, if not outright racist (Pearson, 1975). These critics employed literature to assist in the birth of a liberal intellectual position capable of competing with what they saw as repressive conservative tendencies.

Their examples also indicate the widening of influences on New Zealand's liberal intellectuals in the post-war environment, which continued to accelerate into the 1960s. James K. Baxter and Kendrick Smithyman were noteworthy in moving beyond the cultural nationalists' demand that art be socially significant. Their rejection of McCormick, Holcroft and Curnow 
reflected the growing identification by North Island writers of a 'South Island Myth', which focused on themes of isolation, exile and alienation that had become anathema to North Island writers living in growing metropolitan areas. Their regionalism presupposed an introverted cultural nationalism which was deemed to be inherently unproductive if the South Islanders' aim was to create a sophisticated local culture.

James K. Baxter was himself born in Dunedin, but was of a younger generation to other South Island writers and probably opposed to what he might have viewed as a degree of middle-class gentility not conducive to the creation of great art. He became one of New Zealand's best known intellectual figures (known as much for the alcoholism which killed him in 1972 as his poetry), partly on the basis of a series of literary critical essays published early in his career. 'The Fire and the Anvil' followed T. S. Eliot in asserting that poetry was incapable of healing the modernist schism between man and nature, leading both of them to assert the need for Christianity and hereditary tribal affiliations. This is modernism at its most iconoclastic: not only is the modern world characterized in terms of a 'dissociation of sensibility' (Eliot, cited in Meyer, 2000: 96) but Western liberalism is seen as an insufficient response.

Although retaining an attitude of social responsibility (he set up a remote commune called Jerusalem for drug and alcohol addicts), Baxter felt that the threefold aspect of the modern world was essentially 'monotony, atrocity, anarchy' and that Western liberalism was inadequate (Baxter, 1980: 49). Fascinated by Jungian psychology, he saw the problem of cultural transference from Europe in terms of universal problems of significant moment rather than issues of a purely cultural nature:

They had two choices: to continue writing in an English tradition dissociated from their actual geographical and historical situation; or to begin the immensely difficult task of forging new symbols in a country whose landscape was alien and whose intelligible past was shorter than their own lifespan. (Baxter, 1951: 5)

Despite rejecting his overtly nationalist position, Baxter's thought mirrored Curnow's about the early years of settlement, specifically in the sense of a dissociation of sensibility, a culture in limbo, and a provincial outlook deferred for future generations. Such ideas were common currency throughout the mid-20th-century world, amongst literary critics as varied in approach as T. S. Eliot, Gertrude Stein and F. R. Leavis; Baxter's approach was merely reflective of broader developments across the Western tradition. Isaiah Berlin would characterize him as a Tolstoy-like figure, forever straining to fit experience into an overarching vision (Berlin, 1953).

If Baxter was suggestive of Berlin's 'hedgehog' in his employment of psychological universalism, Kendrick Smithyman presented New Zealand readers with a universalist straining to import the 'objective' approach of the American New Critics into an intellectual field dominated by historical and 
sociological interpretations of literature. Along with Baxter, Smithyman signalled the collapse of the cultural nationalist position in New Zealand letters. Although it remained dominant until the set of cultural shifts associated with the fourth Labour government after 1984 (Mein Smith, 2005: 208ff), it was increasingly beset by opposition from intellectuals across a range of disciplines who viewed it as anachronistic and anathema to attempts to deconstruct the still dominant masculinist, Pakeha conception of national identity: the liberal intellectual solution for post-war New Zealand became the liberal intellectual bogeyman of the final decades. Like Baxter, Smithyman was ahead of his peers in this respect. As early as 1961 he began a series of articles titled 'Post-War New Zealand Poetry', which he published in the small literary periodical Mate and later extended into the only full-length study of poetry yet produced in New Zealand, A Way of Saying (1965). Although better known for his poetry, Smithyman's aim was to oppose the method of the cultural nationalists and undercut the South Island Myth with critical techniques borrowed from the American New Critics.

Contrary to popular belief, although the New Critics are often viewed as formalists who insisted on criticism that looked only at the words on the page (rather than biographical, historical, and social processes), their original impetus lay in a redefinition of the cultural aims of middle America, so their position did in fact continue to assert a social significance for art and literature. They simply opposed the significant moral implications of the literary criticism practised by the likes of Belinsky (in the context of the Cold War this should come as no surprise), which deified the poet as cultural seer and placed the critic in a position of priest or midwife to the burgeoning cultural industry. Instead of relating texts to their social and cultural environment, they focused on the development of critical precepts that could be applied to any text, supposedly allowing a movement from the amateur man of letters towards the professional academic. The New Critics were thus instrumental in the reaction amongst professional literary critics away from socially interested criticism: a direct challenge to New Zealand's cultural nationalists. It was perspicacious of Smithyman to bring them into New Zealand's critical discourse, even if his audience was not yet ready to listen.

Although his writing is often opaque and rambling, Smithyman borrowed some fine points from the Americans, especially about the slippery debate between provincialism and regionalism which had been worked out in the context of the southern states by Allen Tate and lay at the core of the South Island Myth:

regionalism is that consciousness or that habit of men in a given locality which influences them to certain patterns of thought and conduct handed to them by their ancestors ... [w] hen the regional man, in his ignorance, often an intensive and creative ignorance, of the world, extends his own immediate necessities into the world, and assumes that the present moment is unique, he becomes the provincial man. He cuts himself off from the past, and without 
benefit of the fund of traditional wisdom approaches the simplest problems of life as if nobody had ever heard of them before. (Tate, 1955: 365)

In Smithyman's mind, the cultural nationalists were trying to reinvent the wheel and losing their battle against the romanticism they were so quick to identify in New Zealand's late colonial writers:

We find it hard to be objective; we still suspect objectivity in criticism; we distrust and are reluctant to accept attempts to objectify poetry, to remove it from being merely something within a social process. Consequently, our reluctance is enlarged to the point of repudiating what I called the autonomy of the poem. The less objective, the more subjective, the nearer romantic a poem is, the more acceptable it is. What is more romantic is more re-assuring: it is also easier. What is more disturbing we discover the further from romanticism we get, where eventually we have to recognise the force and right of language in itself, and have to appraise what we would sooner ignore, our responsibility to and for our language. (Smithyman, 1962: 44)

Smithyman's critical writing was never widely read, but in fundamental ways 'Post-War New Zealand Poetry' reflected the beginning of the end for cultural nationalism in New Zealand.

Wystan Curnow, the son of Allen Curnow (and named after the modernist poet W. H. Auden), would have agreed with Smithyman's assessment of critical purpose. After graduating from the University of Auckland, Curnow took the increasingly popular decision to study for his doctorate in America rather than Britain. At the University of Pennsylvania he focused on the role of Herman Melville in American and postcolonial literature. After appointments at the University of Rochester and at York University in Toronto, Curnow returned to New Zealand. In 1970 he joined the Auckland English Department as a lecturer, where he was instrumental in developing a new syllabus that included contemporary American literature. In 1973 he published 'High Culture in a Small Province' in an anthology of critical essays which aimed both to define and elaborate a critical tradition. From this time on, Curnow came to be 'a prominent advocate for the avant-garde' (Shieff, 1998: 125) in New Zealand, publishing poetry and criticism in new postmodern literary periodicals like Parallax, And, Splash and Antic.

The younger Curnow published 'High Culture in a Small Province' in an effort to break New Zealand intellectuals out of what he believed was their continuing provincial malaise. In some ways the essay reflected continuity with New Zealand's earlier literary-critical tradition. Curnow quoted directly from Pearson's 'Fretful Sleepers' to make his point that:

in London honest men can, and usually do, avoid or escape from the society of the imposters. In New Zealand many an honest man has been soured, emasculated or turned showman because he cannot get away from the poky little minds that milch and destroy him. (Pearson, cited in W. Curnow, 1973: 164) 
He went on to add to Pearson's thoughts with a passage that appeared to be borne out of bitter experience:

Unless he is careful, most of his friends will be, as Pearson suggests, amateurs, snobs, men who parade a promise they will never fulfill. Sad men, drop-outs, men who lack a certain seriousness. The cumulative impact of these proximities is by no means negligible. Withstanding it is, in fact, one of the peculiar features of the talented artist's or intellectual's experience of alienation in this country. (W. Curnow, 1973: 164)

But Curnow's point was more nuanced than being merely an intellectual diatribe against his culture. Taking up Smithyman's cue, he argued for greater specialization in artistic endeavour, and the development of a sphere of high culture which could protect artists and intellectuals from the general culture. In many ways it was an acceptance of failure as much as mere snobbishness; whereas Chapman and Pearson had identified provincialism in order to educate the nation against it, the younger Curnow identified it in order to offer the little talent present 'psychic insulation'. Critics reacted badly and argued that Curnow's argument represented little more than snobbery, but he wrote a defence of the position into the essay:

The expression 'psychic insulation' is less odd than it seems; we recognise the need for it when we keep quiet in libraries. If, like Yeats, we have a fascination with what's difficult, with puzzles, we too may be drawn to towers, old country houses, celibate solitude or their equivalents. (W. Curnow, 1973: 155)

The essay represents a form of reverse culture shock which nicely evokes the feelings of a committed young poet, critic and artist re-entering his small home country after years spent close to cultural centres of the world. Curnow's essay is best described as a kind of late-modernism, verging on postmodernism. His stance reflected a rejection of a socially engaged cultural nationalism in favour of a rarefied, cosmopolitan and globally-oriented return to aestheticism. New Zealand culture was to be rejected as inadequate, hopelessly provincial and antithetical to the creation of high art.

Postmodernism thus arrived in New Zealand not only in opposition to the implicit elitism of liberal white male academics, but as part of an artistic movement which rejected New Zealand culture and simultaneously aimed to remake the cultural foundations of the country on the basis of feminism and postcolonialism. Like most ideas, postmodernism was not imported 'pure' from the pens of Foucault and Derrida and the art of Duchamp, but in order to overturn the hegemony exerted by an older generation of intellectuals. Postmodernism in New Zealand was deployed in order to deconstruct the cultural nationalist narrative instigated by McCormick, Holcroft and Curnow; to undermine white male academics' moribund claims to authority; and to offer postcolonialism as the solution to social and cultural ills. 
As so often has happened with literary critique in New Zealand, Wystan Curnow's position influenced Allen Curnow's long-time friend and internationally regarded literary critic C. K. Stead's incendiary essay 'From Wystan to Carlos: Modern and Modernism in New Zealand Poetry' (1979), which attempted to forestall postmodernism by declaring that the younger generation of New Zealand poets had misinterpreted just what 'modernism' was; but the cause of socially committed art was lost. Stead's essay only provided more ammunition for the younger generations, by admitting himself that rather than ushering in modernism, the Phoenix generation of poets had only reinvigorated a tired Georgianism:

Instead of God's own country, a land of milk and honey, South Seas Paradise, the land of kowhai gold and Christmas under the pohutukawas, we're presented with a land of mean cities and mortgaged farms, 'a land of settlers / With never a soul at home'. (Stead, 1981 [1979]: 145)

Mark Williams described the situation well:

... Stead's left-liberal activism of the sixties and seventies did not anticipate, and could not accommodate, the radical and fundamentalist politics ... which aimed at nothing less than the remaking of New Zealand as Aotearoa, a country no longer tied nostalgically or culturally to Europe but part of the Pacific, and to which the liberal conscience of the white academic male was merely the smokescreen of the oppressor. (Williams, 1994: 698)

Unlike most other countries, it is possible to date the 'arrival' of postmodernism into the New Zealand intellectual scene with unusual precision: it occurred with the publication of the first issue of And magazine in 1983. With an ironic nod to the Phoenix generation, And was developed by students at Auckland University, with the expressed purpose of making a lightning raid on New Zealand's literary and intellectual establishment and ousting critics like C. K. Stead who seemed to have been propping up the literary establishment for decades. The periodical was planned for obsolescence after only four issues, the aim being to attack the bastions of New Zealand critical theory and undercut the power of established periodicals like Landfall and Islands. The cover of issue one used a still from the western movie The Man From God's Country (MGM, 1954) with the words 'Ready - Coming In' stencilled over the top in a pithy attempt to announce the arrival of post-structural theory with an aspect of popular culture. It was a moment of rare iconoclasm for New Zealand literature and intellectual culture generally and reflected a direct attack on art and criticism which claimed to be socially responsible at the same time as it merely perpetuated old injustices. Those involved were quick to point out that they were importing post-structuralism (that is, a specific and useful tool) as opposed to postmodernism per se, but this distinction fell on deaf ears: it appeared to be French.

Regardless of opposition, it was clear that the And group were implementing strategy. And / 1 began with a statement of intent by Leigh Davis 
which signalled a break from the cultural nationalists' insistence on realism, ${ }^{4}$ as if this were the keystone which would bring the entire edifice crashing down:

A first characteristic [of $A$ nd's view] centres upon the abstraction 'New Zealand literature'... . The abstraction is less elusive if it is employed as a term that isolates the process of reading, writing, and publishing in New Zealand, providing industry contours, and not solely as a term that attempts to describe the (idealised) quality of some literary product. Here this emphasis shift has never been promoted. ... Ignoring the age of this theory, and its crucial dependence on the insistences of Allen Curnow, we assume that the extant metaphor of connection between 'New Zealand' and 'literature' is still the mould or the hook-and-eye model of writing as it is informed by, or connects with, New Zealand reality. (Davis, 1983: 2)

Conversely, Roger Horrocks, who had attended graduate classes at the University of Minnesota and the University of California during the mid 1960s, pressed the case in And / 2 for theory-laden interpretation by offering it as a salve to provincial New Zealand culture and Curnow's 'hook-and-eye model of writing'. His point was cleverly presented in complimentary diagrams which claimed to point out the different attitudes towards theory held across New Zealand intellectual circles (Horrocks, 1984). The aim was to succeed with theory where the cultural nationalists had failed with social commitment:
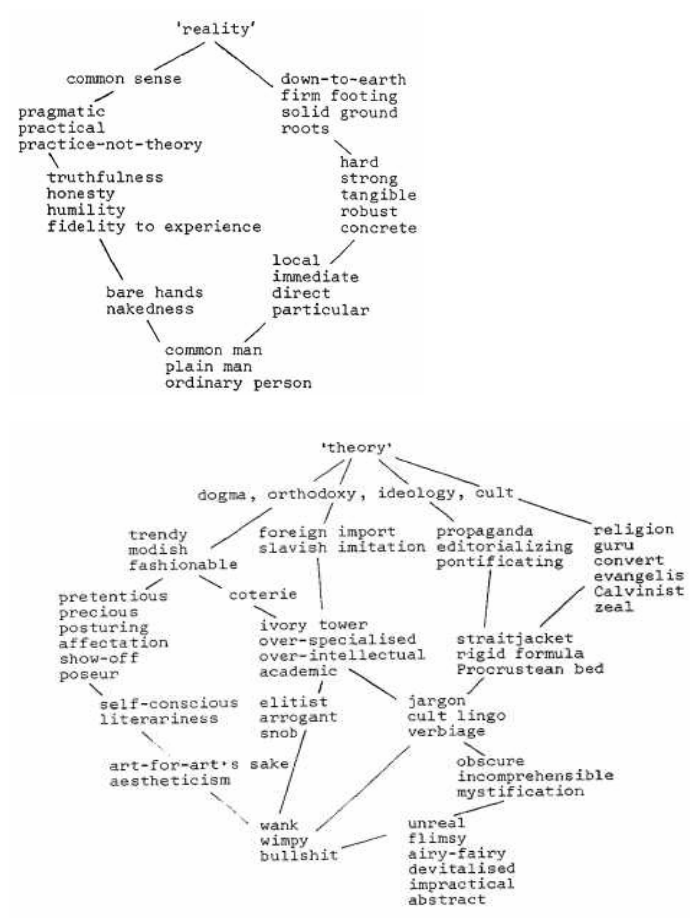
Although it had a small readership, the And group was noticed. The confrontation instigated - between the older generation of literary critics focused on social realism and a new one eager to find new ways to read and create texts - found its way into the $N Z$ Listener during 1983, when Vincent O'Sullivan and MacDonald Jackson responded angrily to a review of their recent anthology of New Zealand writing which labelled it a failure and an example of a mode of 'well worn humanism' (Geraets, 1983a: 98-9) which was both creatively and critically backward. The review was joined by an essay titled 'The New Zealand Anthology - Initiating an Archaeology'. O'Sullivan and Jackson responded that the reviewer got things 'back to front' and included 'contradictory' (Jackson, 1983: 10) information, earning the retort that O'Sullivan's 'introduction to the fiction has locked these and other writers into the habitual terminology of social realism', a term which 'simply does not do good service beyond the 60s' (Geraets, 1983b: 10).

The And group did not aim to be entirely destructive. Another of Horrocks' essays, 'The Invention of New Zealand', provides the best summation of the And group's aims, because it indicates a heartfelt connection to the writing of Curnow and fellow members of his 'reality gang' (Horrocks, 1983: 9). And was not so much an apologia for aestheticism as a critique of cultural nationalism and New Zealand's dominant tradition of social realism.

It is difficult to reduce these late-20th-century New Zealand debates to a simple argument between aestheticism and anti-aestheticism. The cultural terrain is too complicated for such a procedure and although Kendrick Smithyman did offer a position which mitigated the moral force in criticism, while And were frustrated enough with the continuing dominance of the cultural nationalists to launch a mini campaign, it would be going too far to suggest that there was a great rupture in New Zealand's broader literary and intellectual scene. The stance taken by the contributors to And continued in the journal Antic (1986-90), and in some ways the movement against cultural nationalism and social realism did not find full expression until Bill Manhire's creative writing school at Victoria University began producing a string of successful novelists during the 1990s. Although Patrick Evans has seen in this not so much the triumph of postmodernism as the triumph of globalization and slick marketing, it has to be viewed as one belated effect of the movement against cultural nationalism, and indicates that the intellectual terrain took some time to shift.

Similarly, despite aiming to overturn the cultural hegemony of a tradition dominated by Pakeha males, And did not produce a single significant female, Maori or Pacific Island writer; it was essentially a middle-class white male affair. New Zealand did not produce a significant feminist literary-critical essay until Michele Leggott's 'Opening the Archive' in 1995. The And group is more usefully viewed as symbolic of broader cultural changes associated with the Labour government of David Lange (1984-9), which introduced sweeping economic and social reforms. It is widely accepted that these 
policies altered the cultural composition of the country and accelerated a movement away from cultural nationalism towards globalization.

This process accelerated with the commercialization of the university system during the 1990s. A parallel move by English departments to begin cultural studies programmes moved their energies away from literary analysis; these shifts in the structural conditions surrounding New Zealand's literary culture appear to have been co-extensive with reduced demands for the significance of literature within culture and society and a reduction in the public role of literary critics, and hence the tradition of New Zealand literary critique. The cultural nationalist moment - the commitment to social responsibility in art in New Zealand - ended with minimal debate. This effectively rendered the central vehicle for critique of that tradition redundant as well. New Zealand literary critiques have been written sporadically since 1984, but in our present postmodern (and some might say post-nationalist) environment the genre seems to have lost much of its purpose. Literature is no longer viewed as a central bastion of our cultural values, and artists and critics are no longer completely entrusted with the development of our culture. The genre stands as testimony to a period in New Zealand history when writers, intellectuals and academics evinced a somewhat heroic commitment to the elaboration of New Zealand culture beyond 'rugby, racing and beer'.

James Smithies is a Research Associate at the NZ-Australia Connections (NZAC) Research Centre, University of Canterbury, New Zealand. His research interests include the history of literature, ideas and technology. Other related articles on this subject have appeared in The Journal of Commonwealth Literature and The New Zealand Journal of History. [email: james.smithies@canterbury.ac.nz]

\section{Notes}

1. There were some minor examples of literary critique published by New Zealand women prior to 1983-4, but none gained anything like the level of circulation and citation of the men. Some people refer to Robin Hyde's essay 'The Singers of Loneliness', published in the T'ien Hsia Monthly in August 1938, but this had little immediate impact. The most notable example after this - although again almost completely ignored - was Keri Hulme's, 'Mauri: An Introduction to Bicultural Poetry in New Zealand' (1981).

2. See, for example, Raymond L. Williams (1986) and Jeff Guy (1997).

3. Beyond the Breakers (1928); The Flameless Fire (1929); Brazilian Daughter (1931).

4. A stance which Belinsky as much as Curnow would have naturally defended.

\section{References}

Bakhtin, Mikhail (1981) The Dialogic Imagination: Four Essays. Austin: University of Texas Press.

Baxter, James K. (1951) Recent Trends in New Zealand Poetry. Christchurch: The Caxton Press. 
Baxter, James K. (1978 [1954]) 'The Fire and the Anvil: The Macmillan Brown Lectures Given at Victoria University College in June 1954', in Frank McKay (ed.) James K. Baxter as Critic: A Selection of His Literary Criticism, pp. 13-69. Auckland: Heinemann Educational.

Baxter, James K. (1980) 'James K. Baxter', in Robin Dudding (ed.) Beginnings: New Zealand Writers Tell How They Began Writing, pp. 43-9. Wellington: Oxford University Press

Berlin, Isaiah (1978 [1953]) The Hedgehog and the Fox: An Essay on Tolstoy's View of History. Chicago: Elephant Paperbacks.

Berlin, Isaiah (1999) 'Artistic Commitment: A Russian Legacy', in The Sense of Reality: Studies in Ideas and Their History, pp. 194-231. New York: Farrar, Straus and Giroux.

Booker, Anthony James (1983) 'The Centennial Surveys of New Zealand 1936-41', BA (Hons) Research Exercise, Massey University.

Chapman, Robert (1953) 'Fiction and the Social Pattern: Some Implications of Recent New Zealand Writing', Landfall 25(March): 26-58.

Cresswell, W. D'Arcy (1932) 'Culture and Puberty', Phoenix 1(1): 5.

Curnow, Alan (1945) A Book of New Zealand Verse, 1923-1945. Christchurch: The Caxton Press.

Curnow, Wystan (1973) 'High Culture in a Small Province', in Wystan Curnow (ed.) Essays on New Zealand Literature, pp. 155-71. Auckland: Heinemann Educational.

Davis, Leigh (1983) 'Set Up: August 1983', And 1: 1-7.

Davis, Robert and Schleifer, Ronald (1991) Criticism and Culture: The Role of Critique in Modern Literary Theory. Harlow: Longman.

Devitt, Amy J. (1993) 'Generalizing About Genre: New Conceptions of an Old Concept', College Composition and Communication 44(4): 573-86.

Eagleton, Terry (1990) 'Nationalism: Irony and Commitment', in Terry Eagleton, Fredric Jameson and Edward W. Said, Nationalism, Colonialism and Literature, pp. 23-39. Minneapolis: University of Minnesota Press.

Evans, Patrick (2002) 'Spectacular Babies: The Globalisation of New Zealand Fiction', Kite 22: 5-14.

Fairburn, Miles (2006) 'Is There a Good Case for New Zealand Exceptionalism?', in Tony Ballantyne and Brian Moloughney (eds) Disputed Histories: Imagining New Zealand's Pasts, pp. 143-67. Dunedin: Otago University Press.

Frye, Northrop (1957) Anatomy of Criticism: Four Essays. Princeton, NJ: Princeton University Press.

Geraets, John (1983a) 'Review of MacDonald P. Jackson and Vincent O'Sullivan (eds), The Oxford Anthology of New Zealand Writing Since 1945, NZ Listener (30 July): 98-9.

Geraets, John (1983b) 'Letter to the Editor', NZ Listener (24 September): 10.

Geraets, John (1983c) 'The New Zealand Anthology - Initiating an Archaeology', And 1: $66-73$

Guy, Jeff (1997) 'Class, Imperialism and Literary Criticism: William Ngidi, John Colenso and Matthew Arnold', Journal of Southern African Studies 23(2): 219-41.

Hilliard, Chris (2006) The Bookmen's Dominion: Cultural Life in New Zealand 1920-1950. Auckland: Auckland University Press.

Holcroft, M. H. (1943) The Waiting Hills. Wellington: The Progressive Publishing Society. 
Holcroft, M. H. (1948) Creative Problems in New Zealand. Christchurch: The Caxton Press.

Horrocks, Roger (1982) 'An Essay about Experimental Films that Ended Up as an Essay about New Zealand', Parallax 1(1): 78-89.

Horrocks, Roger (1983) 'The Invention of New Zealand', And 1: 9-30.

Horrocks, Roger (1984) 'No Theory Permitted on These Premises', And 2: 119-37.

Hulme, Keri (1981) 'Mauri: An Introduction to Bicultural Poetry in New Zealand', in Guy Armithanayagam and S. C. Harrex (eds) Only Connect: Literary Perspectives East and West, pp. 290-310. Adelaide: Centre for Research in the New Literatures in English.

Jackson, MacD. P. (1983) 'Letter to the Editor', NZ Listener (27 August): 10.

Jackson, MacD. P. and O'Sullivan, V. (eds) (1983) The Oxford Anthology of New Zealand Writing Since 1945. Auckland: Oxford University Press.

Jensen, Kai (1996) Whole Men: The Masculine Tradition in New Zealand Literature. Auckland: Auckland University Press.

Leggot, Michele (1995) 'Opening the Archive: Robin Hyde, Eileen Duggan and the Persistence of Record', in Mark Williams and Michele Leggot (eds) Opening the Book: New Essays on New Zealand Literature. Auckland: Auckland University Press.

Matlaw, Ralph E. (ed.) (1976) Belinsky, Chernyshevsky and Dobrolyubov: Selected Criticism. Bloomington and London: Indiana University Press.

McCormick, E. H. (1935) 'Literature in New Zealand: An Essay in Cultural Criticism'. M. Litt. thesis, Cambridge University.

McCormick, E. H. (1940) Letters and Art in New Zealand. Wellington: Government Printer.

McLeay, Elizabeth (ed.) (1999) New Zealand Politics and Social Patterns: Selected Works by Robert Chapman. Wellington: Victoria University Press.

Mein Smith, Philippa (2005) A Concise History of New Zealand. Melbourne: Cambridge University Press.

Meyer, Steven (2000) 'Gertrude Stein', in A. Walton Litz, Louis Menand, and Lawrence Rainey (eds) The Cambridge History of Literary Criticism, Vol. 7: Modernism and the New Criticism, pp. 93-121. Cambridge: Cambridge University Press.

O'Sullivan, Vincent (1983) 'Letter to the Editor', NZ Listener (27 August): 10.

Pearson, Bill (1952) 'Fretful Sleepers: A Sketch of New Zealand Behaviour and Its Implications for the Artist', Landfall 6 (September): 201-30.

Pearson, Bill (1975) 'The Maori and Literature 1938-1965', in Erik Schwimmer (ed.) The Maori People in the Nineteen-Sixties - a Symposium, pp. 217-56. Auckland: Longman Paul Ltd.

Sargeson, Frank (1973) The Stories of Frank Sargeson. Auckland: Longman Paul.

Shieff, Sarah (1998) 'Wystan Curnow', in R. Robinson and N. Wattie (eds) The Oxford Companion to New Zealand Literature. Auckland: Auckland University Press.

Smithyman, Kendrick (1961-3) 'Post-War New Zealand Poetry', Mate.

Smithyman, Kendrick (1965) A Way of Saying: A Study of New Zealand Poetry. Auckland: Collins.

Stafford, J. and Williams, M. (2006) Maoriland: New Zealand Literature 1872-1914. Wellington: Victoria University Press.

Stead, C. K. (1981 [1979]) 'Preliminary: From Wystan to Carlos: Modern and Modernism 
106 Thesis Eleven (Number 92 2008)

in Recent New Zealand Poetry', in In the Glass Case: Essays on New Zealand Literature, pp. 139-59. Auckland: Auckland University Press.

Tate, Allen (1955 [1945]) 'The New Provincialism', in The Man of Letters in the Modern World: Selected Essays 1928-1955, pp. 321-31. Cleveland and New York: Meridian Books.

Williams, M. and Leggot, M. (eds) (1995) Opening the Book: New Essays on New Zealand Writing. Auckland: Auckland University Press.

Williams, Mark (1994) 'C. K. Stead and the New Literary Order', Meanjin 53(4): 695-703.

Williams, Raymond L. (1986) 'Review: Literary Criticism and Cultural Observation: Recent Studies on Twentieth-Century Latin American Literature', Latin American Research Review 21: 258-69. 